\title{
Environmental Sustainability Criteria in the Coffee Sector - Lessons that Can be Learnt
}

\author{
Evgenia Pavlovskaia \\ Law Faculty, Lund University, Sweden \\ *Corresponding Author: Evgenia.Pavlovskaia@jur.lu.se
}

\begin{abstract}
Copyright (C) 2014 Horizon Research Publishing All rights reserved.
\end{abstract}
\begin{abstract}
In the article, the issue of environmental sustainability criteria in the coffee sector is researched. Such important aspects in this topic are highlighted and discussed as reasons for the emergence of sustainability criteria for coffee and factors that make the production of coffee sustainable. Two widely used sustainability standards for coffee, the Fair Trade Coffee sustainability standard and the Utz Certified Coffee sustainability standard, are investigated more precisely. The environmental requirements of these standards in the form of environmental sustainability criteria, and mechanisms to control their fulfilment are outlined. The issue of control is separately highlighted, because it is considered indispensible for the constructions with sustainability criteria to function as they have been aimed for. Finally, challenges of the present situation in the coffee sector, when there is a variety of co-existing sustainability standards with approximately similar sustainability requirements are reflected upon. The article is aimed to raise interest to the potential of sustainability criteria to promote sustainable products and their sustainable production methods. In the long perspective, sustainability criteria can be used as tool to promote and safeguard sustainability, and particularly environmental sustainability, which is very urgent. The idea is emphasized that the experience of the coffee sector and central aspects of its governance approach towards sustainability can be efficiently shared by other industries with similar problematic issues, e.g. in the biofuel industry.
\end{abstract}

Keywords Sustainability Criteria, Control of
Sustainability Criteria, Fair Trade Coffee Standard, Utz
Certified Coffee Standard, Coffee Production,
Environmental Sustainability

\section{Introduction}

Sustainability criteria are gaining recognition as a tool, which can be efficiently used to promote sustainable products and safeguard their sustainable production. This is relevant for both domestically produced and imported products. The present article investigates the notion of environmental sustainability criteria and control of their fulfilment in the coffee sector, where sustainability criteria have already been used for some time, and valuable practical experience has been generated. The research on this topic is urgent and relevant, because other industries can learn much from the approach to sustainability criteria in the coffee sector and develop similar patterns, where necessary. As an example, key aspects that can be interesting for other industries are how a set of sustainability criteria for a product can be formulated, which issues it should include and how control of the fulfillment of the sustainability criteria should be organized. The issue of control is particularly important in this connection, because without appropriate control mechanisms and administrative bodies that are responsible for control a framework with sustainability criteria will not be able to fulfil its purposes.

\section{Reasons for Sustainability Criteria in the Coffee Sector}

The emergence of voluntary standards for sustainable coffee production has been characterized by the initiatives from NGOs and producing companies, accompanied by connected certification requirements and labels. 1 Aspects that have urged the development of sustainability criteria in the coffee sector have primarily been the lack of concerns about environmental issues, environmental damage that this sector can cause and growing demands from NGOs that have required environmental responsibilities from this industry. 2 It has become noticeable that the main focus in the coffee sector has been on potential economic risks and the economic gain,3 not on environmental issues. By the mid-1990-ies, the development of the coffee industry led to some environmental degradation in developing countries

1 Kolk, A. (2011), Mainstreaming sustainable coffee, p. 2; this process can also be interpreted as a growing public awareness of the positive difference that individual buying choices can make [Davenport, E., Low, W. (2013), From trust to compliance: accountability in the fair trade movement, p. 92]. 2 Rice, P., McLean, J. (1999), Sustainable Coffee at the Crossroads, p. 11.

3 Adams, M.A., Ghaly, A.E. (2007), The foundations of a multi-criteria evaluation methodology for assessing sustainability, p. 445. 
combined with the use of unsustainable fuels for production and transportation, as well as inefficient production technologies. 4 Pressure from NGOs to improve sustainability in the coffee sector has increased. 5 In response, several coffee companies have adopted requirements to the quality of sustainable coffee and sustainable coffee production. They have also started to engage in partnerships with NGOs and governments. 6

\section{What Makes the Production of Coffee Sustainable}

About $90 \%$ of coffee is cultivated in over 60 tropical countries in the South7 and traded to developed countries in the North. 8 Latin America is one of the main exporting regions. There are overlapping international markets for both sustainable and unsustainable coffee. The sustainable coffee market, unlike most of the coffee industry, has experienced much growth in recent years. 9 Among the typical environmental risks that coffee production can have is pressure on land for increased coffee farming, which can force a direct or indirect change in land use.10 Despite the well established production and exporting practices, there is no clearly agreed definition on what sustainable coffee or sustainable production of coffee is. It can be reminded, that the same situation is with the concepts "sustainable biofuels" and "sustainable production of biofuels" in the biofuel sector.

The uncertainty with the definitions in the coffee sector can be explained not by the unwillingness of the involved actors to agree on a commonly accepted definition, but by the difficulty to do so. One of the suggestions is that "sustainable coffee is produced on a farm with high biological diversity and low chemical inputs. It conserves resources, using renewables when possible, minimizes pollution, protects the environment, produces efficiently, competes commercially and enhances the quality of life for farmers and society as a whole."11 As a practical example, a sustainable farm will reuse coffee husks as heating fuel rather than cutting down eucalyptus trees. It will plant new

4 Adams, M.A., Ghaly, A.E. (2007), The foundations of a multi-criteria evaluation methodology for assessing sustainability, p. 437.

5 Kolk, A. (2005), Corporate Social Responsibility in the Coffee Sector: The Dynamics of MNC Responses and Code Development, p. 229 .

6 Bitzer, V., Francken, M., Glasbergen, P. (2008), Intersectoral partnerships for a sustainable coffee chain: Really addressing sustainability or just picking (coffee) cherries?, p. 274.

7 Bitzer, V., Francken, M., Glasbergen, P. (2008), Intersectoral partnerships for a sustainable coffee chain: Really addressing sustainability or just picking (coffee) cherries, p. 271

8 Ponte, S. (2002), The "Latte Revolution"? Regulation, Markets and Consumption in the Global Coffee Chain, p. 1102.

9 Giovannucci, D. (2001), Sustainable Coffee Survey of the North American Specialty Coffee Industry, p. 30

10 Rice, R. (2003), Coffee production in a time of crisis: social and environmental connections, p. 232; see also the reasoning in Biomass Technology Group, BTG (2008), Sustainability Criteria \& Certification Systems for Biomass Production, p. 80.

11 Greenberg, R. (2001), Criteria Working Group Thought Paper, the Smithsonian Institution, p. 1; Rice, R. (2003), Coffee production in a time of crisis: social and environmental connections, p. 237. trees for those used during heating, or it will implement pollution free coffee dryers such as the solar coffee dryer. 12 Thus, a sustainable coffee farm is a farm that produces coffee in a manner friendly to the environment and to people who farm it. 13

Two main groups of sustainability criteria for coffee production can be defined. The first group contains criteria of a more wide-ranging character that after certain generalization can even be applied to other products of an agricultural origin, including energy crops for biofuels. The second group of the sustainability criteria is more specific and reflects details that are special for the production of coffee. Aspects from the second group might have relevance for farming of other sorts of agricultural crops, though it should be researched to what extent and in what form they can be applied there. The content of the first and the second groups is directed by four parameters that regulate the process of coffee production. These parameters can be formulated in the form of the following questions: What is to be produced? How is it to be produced? When is it to be produced? and How much is to be produced? 14

The first group of the wide-ranging sustainability criteria includes regulations of such important issues at various stages of coffee production as use of pesticides and fertilizers, land use, protection of biodiversity, cleaning of wastewater, improvement of drying systems, proper recycling of by-products, 15 and minimization of water consumption. 16 The majority of environmental challenges that are mentioned here can occur when energy crops for the production of biofuels are cultivated, which means that the experience from the coffee sector can be shared.

The content of the second group of the special sustainability criteria for coffee production is determined by special features of coffee farming. Coffee has traditionally been grown among forest trees, in the shade. This production method facilitates the achievement of high yields, discourages weed growth and can reduce pathogen infections, as well as protect crops from frost. It is often thought to give better taste, because the long ripening period adds to nourishing flavors. 17 From the environmental perspective, coffee grown in the shade contributes to the preservation of biodiversity and eco-systems in areas, where coffee plantations are located.18 It helps to increase the number of pollinators and provides a natural habitat for birds to feed and rest. To produce coffee faster and prevent the spread of coffee leaf rust, many coffee producers have started to grow coffee under sunnier conditions, in some cases under the full Sun. The increase of non-shade coffee plantations has in

12 Coffee Politics: Coffee Issues and Social Aspects, Coffee Sustainability. 13 Montavlo, K. (2006), Beans and Leaves, p. 87.

14 Bitzer, V., Francken, M., Glasbergen, P. (2008), Intersectoral partnerships for a sustainable coffee chain: Really addressing sustainability or just picking (coffee) cherries, p. 273

15 Adams, M.A., Ghaly, A.E. (2007), The foundations of a multi-criteria evaluation methodology for assessing sustainability, p. 440.

16 Coffee Politics: Coffee Issues and Social Aspects, Coffee Sustainability. 17 Montavlo, K. (2006), Beans and Leaves, p. 88.

18 Borkhataria, R., Collazo, J. A., Groom, M. J., Jordan-Garcia, A. (2012). Shade-grown coffee in Puerto Rico: Opportunities to preserve biodiversity while reinvigorating a struggling agricultural commodity, p. 165. 
many cases a negative impact on the environment. 19 This production method can minimize natural shelters for birds, and intensify the use of chemical fertilizers, insecticides and pesticides to accelerate growth. The latter aspects, in turn, result in toxic water runoff and pollution of habitats for many species. It can be recommended to include in the second group such sustainability criteria that protect and safeguard growing coffee in the shade.

Some of the previous investigations have shown that coffee quality can be more important for customers than price. 20 Demands of the customers and convenience of supply have in turn shown to be the most significant criteria for industry purchasing decisions. Consistency of supply has ranked second in importance, which is understandable, taking into account the costs and risks of sourcing from new suppliers. 21

\section{Examples of Voluntary Sustainability Standards for Coffee}

Sustainability criteria for coffee, as well as sustainability criteria for any product of an agricultural origin, can be classified according to different principles. One of the classification approaches is that criteria for coffee are divided according to their purpose. For example, sustainability purposes and corporate purposes can be distinguished. Corporate purposes are those associated with the continued economic growth. They are largely focused on economic circumstances and maintenance of well-functioning governmental relationships. Sustainability purposes can be defined as factors associated with sustainable development and long-lasting environmental impacts, in particular factors that have influence on sustainability of the coffee industry in the long term. 22 Sustainability standards can vary noticeably according to their sustainability and corporate purposes, which in turn has influence on the content of sustainability criteria. I am keeping the focus of the research on the sustainability purposes that have environmental relevance.

Among the most popular sorts of sustainable coffee that correspond to a particular sustainability standard, there are Fair Trade Coffee, Organic Coffee, Utz Certified (earlier called "the Utz Kapeh Foundation") Coffee, Shade or Bird-friendly Coffee and Rainforest Alliance Coffee. Each of these standards has a non-governmental background, distinct purpose, date of entering in force, and set of priorities that form the content of sustainability criteria and

19 Rice, R. (2003), Coffee production in a time of crisis: social and environmental connections, p. 232.

20 See for example about coffee consumption patterns in China in Smith Maguire, J., \& Hu, D. (2013). Not a simple coffee shop: local, global and glocal dimensions of the consumption of Starbucks in China, p. 6; or a research about luxury café culture in South Korea in Kim, D., \& Jang, S. S. (2013), Price Placebo Effects: Consumers May Get What They Pay For, p. 111.

21 Giovannucci, D. (2001), Sustainable Coffee Survey of the North American Specialty Coffee Industry, p. 4.

22 Adams, M.A., Ghaly, A.E. (2007), The foundations of a multi-criteria evaluation methodology for assessing sustainability, p. 441 procedures. Some special features of the most popular sustainability standards for coffee, starting with the Fair Trade Coffee standard are mentioned below.

\subsection{Fair Trade Coffee Sustainability Standard}

The Fair Trade Coffee sustainability standard is a part of a larger Fair Trade international certification system that allows people to identify products that meet agreed environmental, labor and developmental standards. The Fair Trade certification system covers a growing range of products, including bananas, honey, oranges, cocoa, coffee, shortbread, cotton, dried and fresh fruits and vegetables, juices, nuts and oil seeds, rice, spices, sugar, tea and wine. 23

Fair Trade standards are set in accordance with the ISEAL 24 Code of Good Practice on Standard Setting. This process involves wide consultation with stakeholders. 25 Fair Trade standards include requirements for environmentally sound agricultural practices. 26

\subsubsection{General Information about the Fair Trade Coffee Sustainability Standard. Regulatory Documents}

The establishment of Fair Trade Coffee sustainability standard started during the 1980-ies.27 It is currently open to small producer organizations only. Small farmers must be organized in organizations, which they own and democratically govern. 28

The sustainable production of coffee is regulated through the 2011 Fair Trade Standard for Coffee for Small Producer Organizations 29 that should be used together with the

23 Fair Trade web-site, http://www.fairtrade.net/products.0.html, last visited 29-08-2013; Moore, G. (2004), The Fair Trade Movement: Parameters, Issues and Future Research, p. 75; Raynolds, L., Murray, D., Taylor, P. (2004), Fair trade coffee: building producer capacity via global networks, p. 1110; Kocken, M. (2006), Sixty Years of Fair Trade, a brief history of the Fair Trade movement, p. 2; Haight, C. (2011), The Problem with Fair Trade Coffee; Coffee has been the first product to get the Fair Trade sustainability certification. Forty percent of all Fair Trade certified farmers in the world produce coffee; far more farmers than any other certified product [Elder, S. D., Zerriffi, H., le Billon, P. (2013), Is Fairtrade certification greening agricultural practices? An analysis of Fairtrade environmental standards in Rwanda, p. 265].

24 ISEAL is a non-governmental organization, which mission is to strengthen sustainability standards systems for the benefit of people and the environment. Its membership is open to all multi-stakeholder sustainability standards and accreditation bodies that demonstrate their ability to meet the ISEAL Codes of Good Practice and accompanying requirements [ISEAL web-site, http://www.isealalliance.org/about-us, last visited 29-08-2013].

25 Fair Trade web-site, http://www.fairtrade.net/setting-the-standards.html, last visited 29-08-2013.

26

http://www.fairtrade.net/aims-of-fairtrade-standards.html, last visited 29-08-2013.

27 In 1988 a coalition of economic justice activists created the first Fair Trade certification initiative in the Netherlands, called Max Havelaar, after a fictional Dutch character who opposed the exploitation of coffee farmers by Dutch colonialists in the East Indies [Low, W., Davenport, E. (2006),

Mainstreaming fair trade: adoption, assimilation, appropriation, p. 319; Murray, D., Raynolds, L., Taylor, P. (2006), The future of Fair Trade coffee: dilemmas facing Latin America's small-scale producers, p. 181; Fair Trade Coffee: A Growing Market Trend (2007); Haight, C. (2011), The Problem with Fair Trade Coffee].

28 Raynolds, L., Murray, D., Taylor, P. (2004), Fair trade coffee: building producer capacity via global networks, p. 1111; Murray, D., Raynolds, L., Taylor, P. (2006), The future of Fair Trade coffee: dilemmas facing Latin America's small-scale producers, p. 182; Fair Trade web-site, coffee section, http://www.fairtrade.net/coffee.html, last visited 29-08-2013.

29 Fair Trade International (2011), Fair Trade Standard for Coffee for Small Producer Organizations. 
overwhelming 2011 Standard for Small Producer Organizations 30. The 2011 Standard for Small Producer Organizations states that Fair Trade is a strategy, which aims to promote sustainable development and to reduce poverty through fairer trade. 31 It distinguishes between core requirements, which producers must meet to be certified, and development requirements that encourage producers to continuously improve and invest in the development of their organizations and their workers. $32 \mathrm{~A}$ producer is in compliance with the Fair Trade Standard for Small Producer Organizations, if he or she fulfils all core requirements and reach the minimum score on the development requirements. 33 Each requirement is assigned a number, e.g. $0,1,3$ or 6 . This number represents the number of years a producer has until he or she is audited against the requirement. Some requirements may not apply to a particular producer. 34

\subsubsection{Environmental Requirements}

The 2011 Fair Trade Standard for Small Producer Organizations has four Chapters: General Requirements, Trade, Production, and Business and Development. The Chapter "Production" contains the section "Environmental Protection".35 The intend and scope of this section is to ensure that the producer and members of his or her organization have agricultural and environmental practices that are sustainable and minimize risks, as well as that biodiversity is protected and enhanced.36 Environmental protection covers such issues as pest management, proper use of pesticides and other hazardous chemicals, protection of soil and water quality, appropriate waste management and no use of genetically modified organisms (GMOs). Environmental concerns are integrated into the development requirements, on which producer organizations must show continuous improvement. 37

More detailed, the 2011 Standard for Small Producer Organizations promotes the use of integrated pest management tools, and aims at reducing the amounts of used pesticides as much as possible. When pesticide use is necessary, a producer and members of his or her organization are encouraged to use pesticides that are the least toxic as economically and technically feasible. 38 A producer must provide training to his or her members on the subject of

30 Fair Trade International (2011), Fair Trade Standard for Small Producer Organizations.

31 Fair Trade International (2011), Fair Trade Standard for Small Producer Organizations, Purpose.

32 Fair Trade International (2011), Fair Trade Standard for Small Producer Organizations, How to use this Standard; Fair Trade web-site, http://www.fairtrade.net/aims-of-fairtrade-standards.html, last visited 29-08-2013.

33 Fair Trade International (2011), Fair Trade Standard for Small Producer Organizations, How to use this Standard; Fair Trade web-site, http://www.fairtrade.net/aims-of-fairtrade-standards.html, last visited 29-08-2013.

34 Fair Trade International (2011), Fair Trade Standard for Small Producer Organizations, How to use this Standard.

35 Section 3.2.

36 See an introductory note to Section 3.2 Environmental Protection.

37 Bitzer, V., Francken, M., Glasbergen, P. (2008), Intersectoral partnerships for a sustainable coffee chain: Really addressing sustainability or just picking (coffee) cherries?, p. 278.

38 Section 3.2 Environmental Protection, Intent and scope. integrated pest management. 39

Proper use and handling of pesticides and other hazardous chemicals involves, according to the 2011 Standard for Small Producer Organizations, that a producer must provide training to his or her members and workers, who handle pesticides and other hazardous chemicals on the risks of handling these materials and on how to handle them properly.40 A producer must compile a list of the pesticides that are used on Fair Trade crops and keep it updated, at a minimum every 3 years. 41 In the Annex, the Standard contains a list of prohibited chemical materials.

Dealing with the protection of soil and water quality, a producer must report on measures that he or she as an organization has implemented to improve soil fertility. Measures can include practices such as crop rotation, intercropping, agroforestry, the use of ground covers, or incorporating compost or green manures into the soil. 42 Sources of water used for irrigating and processing Fair Trade crops must be listed. 43 A producer must provide training to the members of his or her organization on measures to use water efficiently. 44

Waste should be reduced, reused, handled and recycled in a manner that is appropriate to the respective materials. Risks from hazardous waste should be reduced. Waste management should lead to an improved environment and work place. 45 Genetically engineered seeds or planting stocks must not be used intentionally by the producers certified to the Fair Trade sustainability standards. Practices must be implemented to avoid contamination by genetically modified organisms in seed stocks. 46

In questions of biodiversity, producers must avoid negative impacts on protected areas and in areas with high conservation value within or outside the farm or production areas. The areas that are used or converted to the Fair Trade production must comply with national legislations in relation to agricultural land use. 47 Aspects of energy and GHG emissions should also be taken into account. In central processing facilities, where non-renewable energy is used, a producer must keep records of energy consumption, take measures to use energy more efficiently and replace non-renewable sources by renewable ones as far as possible.48 A producer must report on practices that he or she, or the members of his or her organization carry out to reduce GHG emissions and increase carbon sequestration. 49

The 2011 Fair Trade Standard for Small Producer Organizations supports planning activities.50 A producer must plan and document at least one activity with the intention to promote the progress of his or her business,

\footnotetext{
39 Section 3.2 Environmental Protection, unit 3.2.2.

40 Section 3.2 Environmental Protection, unit 3.2.4.

41 Section 3.2 Environmental Protection, unit 3.2.15.

42 Section 3.2 Environmental Protection, unit 3.2.23.

43 Section 3.2 Environmental Protection, unit 3.2.24.

44 Section 3.2 Environmental Protection, unit 3.2.26.

45 Section 3.2 Environmental Protection, Waste, Intent and scope.

46 Section 3.2 Environmental Protection, unit 3.2.32.

47 Section 3.2 Environmental Protection, unit 3.2.33.

48 Section 3.2 Environmental Protection, unit 3.2.39.

49 Section 3.2 Environmental Protection, unit 3.2.40.

50 Section 4.1 Development Potential.
} 
organization, members, workers, community and/or environment. The plan is called the Fair Trade Development Plan.51 The results of the Fair Trade Development Plan must be reported to the General Assembly of the producer's organization every year. 52 Planning activities have the potential to make environmental protection more efficient.

The 2011 Fair Trade Standard for Coffee for Small Producer Organizations contains more detailed product descriptions and rules for pricing. It has no additional information about environmental issues or other topics relevant for the present research.

\subsubsection{Control System}

The control system within the Fair Trade International is headed by two main bodies: the Fair Trade International Labelling Organization (FLO), which is a standard-setting body, and FLO-CERT, which is a certification body.53 The Fair Trade International (FLO) was established in 1997.54 Its agencies are located in 18 European countries, as well as in Canada, the US, Japan, Australia and New Zealand. To ensure the transparency and the independence of the Fair Trade certification and labelling system, the Fair Trade standards are developed and reviewed by the FLO Standards and Policy Committee, in which FLO members, producer organizations, traders and external experts participate. FLO-CERT ensures that producers and traders comply with the Fair Trade sustainability standards and that producers invest the benefits received through Fair Trade in their development. Operating independently from any other interests, FLO-CERT follows the international ISO standards for certification bodies, namely ISO 6555 that contains the international quality norm for certification bodies.

The Fair Trade certification approach received ISO accreditation in October 2007. ISO 65 accreditation means:

- Independence: a certification body must be independent of any external pressure being able to influence a certification decision.

- Transparency: the evaluation and certification processes must be transparent and explained to all parties before inspection.

- Quality: certification decisions can only be consistent and suitable if there are proper internal control mechanisms. The existence of a quality control system, for example, supported by regular internal audits, is essential to identify problems and continuously improve service.

- Equality: all producers must be treated equally.

Today FLO-CERT inspects and certifies producer

51 Section 4.1 Development Potential, unit 4.1.1.

52 Section 4.1 Development Potential, unit 4.1.6.

53 Among the aims to create international controlling bodies there was an intention to instill the consumer with confidence in the Fair Trade process [Fox, T. (2007), The Coffee System: What Standard, What Means? "Fair Trade" and "UTZ", p. 10].

54 Moore, G. (2004), The Fair Trade Movement: Parameters, Issues and Future Research, p. 75.

55 Elder, S. D., Zerriffi, H., le Billon, P. (2013), Is Fairtrade certification greening agricultural practices? An analysis of Fairtrade environmental standards in Rwanda, p. 265. organizations in more than 70 countries in Europe, Africa, Asia and Latin America.56

The Fair Trade control system involves independent auditing of the certified producers to ensure that the agreed Fair Trade standards are met as they should. FLO-CERT works with a network of 120 independent inspectors that yearly visit all involved organizations, both producers and traders, and report back to FLO-CERT. The audit methodology is tailor-made for the evaluation of the Fair Trade sustainability standards. The inspectors are locally based in the country of auditing or a neighboring country. They are familiar with the local culture, law and language. The time the inspector spends on the ground depends on the size of the producer organization, the complexity of the producer organization and the number of certified products they are seeking to sell. A full Fair Trade inspection can take from 4 to 5 days for a small producer organization, and up to six or seven weeks for larger production unions.

No producer organization can be certified without an initial physical inspection. FLO-CERT operates a group certification model, which includes the inspection of the central organization and random checks of a representative sample of individual farmers. The size of the sample is normally based on a square root approach, which is standard practice in group certification. Renewal of the certificate is based on an annual physical inspection. In exceptional circumstances, where they have demonstrated a very good compliance record over the previous years, producer organizations may qualify for a desk top review as part of a three year inspection cycle. This can lead to valuable cost savings for the certified producers.

The cost of the certification is based on the number of working days required for inspection of the producer group. It is not based on the volumes of products sold to the Fair Trade market. Following an inspection, a report is sent to FLO-CERT for evaluation. The evaluator submits a recommendation to the managers of FLO-CERT whether this producer should be certified. The final certification decisions are taken by the Director. A further quality control takes place every two months when the external Certification Committee reviews the decisions of FLO-CERT and provides additional guidance.

It is prescribed in the 2011 Fair Trade Standard for Small Producer Organizations that the producers must accept audits of their premises and provide information at the certification body's request. 57 The producers must appoint a contact person for all certification matters. This person must keep the certification body updated with contact details and important information. 58

FLO-CERT has also developed a trade auditing system to monitor traders compliance with the Fair Trade sustainability

56 The steps to be followed for certification can be divided into: application, initial inspection, evaluation, acquiring certification and after certification [Dörr, A., C. (2009), A Comparative Analysis of Certification Schemes in the Brazilian Fruit Sector, p. 226].

57 Fair Trade International (2011), Fair Trade Standard for Small Producer Organizations, Section 1.1 Certification, unit 1.1.1.

58 Section 1.1 Certification, unit 1.1.2. 
standards and that traders pay the Fair Trade Premium to producers. The system was created to check that every Fair Trade labelled product sold to a consumer has indeed been produced by a certified producer organization, which has been paid the Fairtrade price.59 A network of inspectors conduct trade certification, supported by staff at FLO-CERT headquarters in Bonn. Similarly to producer certification, trade certification decisions are taken by a different person from the one who evaluated the organization and wrote the inspection report. An independent Certification Committee meets every two months to advise FLO-CERT on certification decisions and policies and to maintain an overview of decision making. It comprises a balance of key stakeholders such as certified operators, independent certification experts and consumer representation. The most complex cases are sent to this Committee for Evaluation.

Traceability at different stages is an important factor within the Fair Trade control system. The producers must write down the product flow from the members of the producer organization to the first buyer.60 They must keep records of products sourced from the members.61 When a producer sells a Fair Trade product, he or she must identify clearly in the related documents, e.g. invoices or delivery notes, that this product is Fair Trade. 62 Internally, the producers must define and implement a procedure to monitor and evaluate the performance of their organization members. 63

Companies, which offer products that meet the Fair Trade standards, may apply for licenses to use the Fair Trade Certification Mark for these products. Fair Trade licensees are also subjected to auditing.

\subsubsection{Commentaries}

The Fair Trade Coffee sustainability standard provides an impression of a well-thought and serious system. The central documents that regulate this standard are reviewed and renewed regularly. The division of requirements into core and developmental, as well as setting years, when the developmental requirements are to be fulfilled is an interesting approach. It makes the whole system flexible. The same approach can be tested within other production branches.

Another advantage of the Fair Trade Coffee sustainability standard is that it provides short explanations and guidance information to its provisions directly in the central documents. The requirements are clearly written. Uncertainty is avoided. Long going interpretations, which can be needed in the case of legal regulations, do not seem to be necessary. This makes the use of the Fair Trade Coffee

59 There has been a tendency to view the Fair Trade approach to certification as traditionally based on trust rather than on compliance with specific regulations of performance. However, the situation is changing in line with the development of auditing-based control mechanisms that require compliance with the externally designed sustainability criteria [Davenport, E., Low, W. (2013), From trust to compliance: accountability in the fair trade movement, p. 98].

60 Section 2.1 Traceability, unit 2.1.2.

61 Section 2.1 Traceability, unit 2.1.3.

62 Section 2.1 Traceability, unit 2.1.4.

63 Section 3.1 Management of Production Practices, unit 3.1.4. sustainability standard practical.

The issues that are considered in the section "Environmental protection" have a broad scope. The most significant areas of environmental protection are regulated.

A weakness of the Fair Trade Coffee sustainability standard is that it is clearly limited to small producers. It has also been unable to certify the total production of registered organizations. In 2001, the volume of the total sales of certified Fair Trade coffee was only 13,6\% of the total production of registered producers. This indicates a large gap between potential and actual sales of sustainable coffee. 64

\subsection{The Utz Certified Coffee Sustainability Standard}

The UTZ Certified, earlier with the name "the Utz Kapeh Foundation", is a joint program for sustainable farming of agricultural products. It is responsible for sustainability standards and labeling of coffee, cocoa and tea. The word "Kapeh-Utz" translates from Mayan Kaqchikel as "good coffee". 65 The Utz Certified Coffee sustainability standard is the youngest coffee standard that was originated in 2002. 66 In 2007, the Utz Kapeh Foundation officially changed its name and logo to the UTZ Certified.

\subsubsection{General Information about the Utz Certified Coffee Sustainability Standard. Regulatory Documents}

The goal of the UTZ Certified Coffee sustainability standard is to create a sustainable, viable coffee market through an efficient certification and traceability program for socially and environmentally responsible coffee production that meets the needs of both producers and markets. 67

Actors involved in the Utz Certified Coffee sustainability standard, such as coffee producers, cooperatives, estate farms and producer groups, comply with the main regulatory document, which is the Utz Certified Code of Conduct. 68 This Code is an internationally recognized set of sustainability criteria for professional coffee growing that includes principles for environmentally and socially appropriate coffee growing practices and farm management. The emphasis of the Utz Kapeh Code of Conduct is on compliance with local environmental and labor laws and good management practices. 69 The 2010 version of this

64 Muradian, R., Pelupessy, W. (2005), Governing the Coffee Chain: The Role of Voluntary Regulatory Systems, p. 2033.

65 Sexsmith, K., \& Potts, J. (2009), Voluntary Sustainability Standards and Value Chain Governance, p. 53.

66 The intention behind the development of the Utz Kapeh sustainability standard has namely been to improve upon the Fair Trade sustainability standard, which allowed the participation of small farmers only [Ingenbleek,

P. T., \& Reinders, M. J. (2013), The development of a market for sustainable coffee in the Netherlands: Rethinking the contribution of fair trade, p. 468]. 67 The UTZ Certified, Coffee, https://www.utzcertified.org/en/products/coffee, last visited 02-09-2013. 68 The UTZ Certified (2010), Code of Conduct for Coffee, November 2010.

69 Muradian, R., Pelupessy, W. (2005), Governing the Coffee Chain: The Role of Voluntary Regulatory Systems, p. 2035; Sexsmith, K., \& Potts, J. (2009), Voluntary Sustainability Standards and Value Chain Governance, p. 5; the Utz Kapeh approach to sustainability of coffee has been based on the EurepGAP Protocol for Fruits and Vegetables. This Protocol has been developed by the leading European retailers to provide basic assurance for food safety and environmentally and socially appropriate growing practices. 
Code has good agricultural practices and international conventions as its basis.

There are two additional documents that provide extra explanations to the Utz Certified Code of Conduct: the "Guidance comments" and the "ICS70 guidance comment". The "Guidance comments" give extra explanations on how to comply with control points in the Utz Certified Code of Conduct. The "ICS guidance comment" is a reference for producer groups on how to interpret and implement the control points in a group certification with an internal control system and internal management system (IMS). 71

\subsubsection{Environmental Requirements}

The sustainability criteria of the Utz Certified Code of 2010 fall into three categories: good agricultural and business practices, environmental criteria and social criteria. The group of the social criteria is omitted in the present discussion because of the limitations of the research topic. The good agricultural and business practices in the Utz Certified Code of 2010 deal with such aspects as monitoring business processes, record-keeping of fertilizers and agro-chemicals, traceability of coffee and annual inspections. The environmental criteria include the issues of reduction and prevention of soil erosion, responsibility for and minimal use of agrochemicals, implementation of special programs for pest management, minimization of water use and environmental pollution, minimization of energy use, protection of water sources, special treatment of contaminated water, protection of primary forests, use of native tree species as coffee shade trees and protection of endangered species. 72

The issue of soil management in the Utz Certified Code of 2010 is about maintaining the structure and improving the fertility of the soil and to prevent soil erosion. 73 The state of soil fertility is to be assessed.74 The producer is to use practices to conserve and recuperate soil structure and fertility, 75 as well as techniques to prevent soil erosion. 76 The use of fertilizers is to be appropriate for the situation. It is to be recorded. 77

In the issue of sustainable water use, rational use of irrigation water is promoted. Irrigation water is not to contaminate the coffee or the soil.78 The producer is to make rainfall records and use systematic rainfall forecast methods to decide on the application of irrigation water.79

Utz Kapeh has translated the EurepGAP Protocol into a specific framework for the production of coffee. Relevant chapters and criteria from the ILO (International Labour Organisation) Conventions and the Universal Declaration of Human Rights have been added later [Slob, B. (2006). A fair share for smallholders. A value chain analysis of the coffee, p. 13].

70 ICS stands for an internal control system.

71 The UTZ Certified (2010), Code of Conduct for Coffee, p. 7.

72 The UTZ Certified (2010), Code of Conduct for Coffee.

73 The UTZ Certified (2010), Code of Conduct for Coffee, p. 14, section 4

74 The UTZ Certified (2010), Code of Conduct for Coffee, p. 14, section 4.A.1.

75 The UTZ Certified (2010), Code of Conduct for Coffee, p. 14, section 4.A.2.

76 The UTZ Certified (2010), Code of Conduct for Coffee, p. 15, section 4.A.3.

77 The UTZ Certified (2010), Code of Conduct for Coffee, p. 15, section 5.

78 The UTZ Certified (2010), Code of Conduct for Coffee, p. 16, section 6

79 The UTZ Certified (2010), Code of Conduct for Coffee, p. 16, section
The producer is to have a water action plan to optimize irrigation water use and reduce loss and waste of water. 80 Irrigation water is to be extracted from sustainable sources. 81

Section 7 in the Utz Certified Code of 2010 contains requirements to crop protection products, their use, storage and application. These products are to be used with the least chemical toxicity possible for people, flora and fauna. 82 The protection of coffee against pests, diseases and weeds is to be done with the appropriate minimum input of crop protection products. 83

The Utz Certified Code of 2010 requires appropriate harvesting 84 and post-harvesting 85 procedures. The issue of natural resources and biodiversity is regulated in section 11 there. 86 It states that the producer is to conduct an environmental risk assessment.87 The producer is to make and implement an action plan how to address possible environmental risks. Implemented actions are to be documented. 88

The aspect of land use is thoroughly regulated in the Utz Certified Code of 2010. Degradation and deforestation of primary forest is prohibited. The producer is to demonstrate that there has been no degradation and deforestation of primary forest in the 24 months prior to the date of first registration with the Utz Certified. 89 The producer is to re-forest and stimulate ecological restoration of areas that are not used for agricultural production on the farm as much as possible. 90 Coffee production is not to take to place in protected areas. 91

Regarding energy sources and use, the producer is to record and monitor the use of energy in production and processing. 92 The producer is to demonstrate that measures are taken to use energy more efficiently on the farm. 93 The producer is to use renewable energy sources on the farm whenever possible. 94 The producer is to use by-products of coffee growing and processing as fertilizer, compost, mulch or energy source. 95

6.A.1.

80 The UTZ Certified (2010), Code of Conduct for Coffee, p. 16, section 6.B.1.

81 The UTZ Certified (2010), Code of Conduct for Coffee, p. 17, section 6.D.1.

82 The UTZ Certified (2010), Code of Conduct for Coffee, p. 17, section 7.A.4.

83 The UTZ Certified (2010), Code of Conduct for Coffee, p. 17, section 7.A.9.

84 The UTZ Certified (2010), Code of Conduct for Coffee, p. 20, section 8. 85 The UTZ Certified (2010), Code of Conduct for Coffee, p. 21, section 9. 86 The UTZ Certified (2010), Code of Conduct for Coffee, p. 28, section 11. 87 The UTZ Certified (2010), Code of Conduct for Coffee, p. 28, section 11.A.1.

88 The UTZ Certified (2010), Code of Conduct for Coffee, p. 28, section 11.A.2.

89 The UTZ Certified (2010), Code of Conduct for Coffee, p. 28, section 11.C.1.

90 The UTZ Certified (2010), Code of Conduct for Coffee, p. 28, section 11.C.6.

91 The UTZ Certified (2010), Code of Conduct for Coffee, p. 28, section 11.C.7.

92 The UTZ Certified (2010), Code of Conduct for Coffee, p. 29, section 11.D.1.

93 The UTZ Certified (2010), Code of Conduct for Coffee, p. 29, section 11.D.2.

94 The UTZ Certified (2010), Code of Conduct for Coffee, p. 29, section 11.D.3.

95 The UTZ Certified (2010), Code of Conduct for Coffee, p. 29, section 
If a producer, certified by the Utz Coffee sustainability standard, starts to plant GMO coffee, or if there is involvement in plantings of GMO coffee, the producer must inform the Utz Certified and the buyer. All the relevant regulations with regard to GMO in the country of production are to be complied with. 96

\subsubsection{Control System}

Among the main control mechanisms in the Utz Certified Coffee sustainability standard is the involvement of independent auditors. Their task is to make annual inspections of coffee producers with the purpose to check their compliance with the Utz sustainability standard. Responsibility for the inspections lies on independent certification bodies that are certifiers with the International Organization for Standardization (ISO). All the records and documents requested by the Utz Certified Code of Conduct are to be accessible for the independent auditors. 97 Agronomists and technical consultants, hired and trained by the Utz Certified can assist producers in the fulfillment of the Utz sustainability criteria for coffee. The trained personnel can advise on practical implementation of elements of the Utz Certified Code requirements, as well as give directions on improvement of efficiency in farm management. The involvement of independent auditors is to be complemented by self-inspections of coffee producers that are to be made at least once a year. 98

The distinctive feature of the Utz Certified approach to control is traceability. 99 The control system answers two main questions: where the coffee comes from and how it was produced. The aim is that the UTZ Certified coffee is traceable from producer to roaster to consumer. 100 The Utz Certified sustainability standard operates a track-and-trace system, which shows its consumers exactly where the coffee comes from. Some coffee brands and retailers provide their customers with transparency through online coffee tracers. Tools used by the Utz Certified to create and safeguard traceability are the Utz Certified web-based traceability system, which can be followed at the Utz Certified web-site, and the Chain of Custody requirements.

The web-based traceability system functions as follows: when an Utz certified coffee producer sells his or her coffee to a registered Utz certified buyer, the coffee is announced in the Utz certified web-based system. The Utz assigns a unique tracking number to this lot of coffee. This Utz number follows the coffee through the whole coffee chain. At the end

11.D.4.

96 The UTZ Certified (2010), Code of Conduct for Coffee, p. 14, section 3.B.1.

97 The UTZ Certified (2010), Code of Conduct for Coffee, p. 12, section 2.A.3.

98 The UTZ Certified (2010), Code of Conduct for Coffee, p. 12, section 2 B. 1 .

99 Kolk, A. (2011), Mainstreaming sustainable coffee, p. 11; The Utz Certified operates a traceability system that is also being used to track products not using the Utz Certified label, such as RSPO-certified palm oil [Trade Standards Practitioners Network, TSPN, (2010), Food-related Voluntary Sustainability Standards: A Strategy Guide for Policy Makers, p. 23].

100 The UTZ Certified, Coffee, https://www.utzcertified.org/en/products/c offee, last visited 02-09-2013. of the coffee chain, the roaster uses the unique tracking number to know where his or her coffee has been grown.

The Chain of Custody requirements are a part of the Utz Certified Coffee sustainability standard. They include chain-wide administrative and technical rules that are aimed to ensure traceability and guarantee that coffee with an Utz Certified trademark does indeed come from an Utz certified producer. The Chain of Custody requirements also contain criteria for distinguishing the Utz Certified coffee from non-Utz Certified sorts and for keeping records of direct suppliers and buyers.

\subsubsection{Commentaries}

Some critics have called the Utz sustainability standard "Fair Trade light" due to the mild character of its requirements. The criteria of the Utz sustainability standard offer producers no minimum or guaranteed price for their crops. Producers, who are certified for this standard, are therefore highly vulnerable to changes and unpredictability of the coffee market.

Traceability, which is the strong side of the Utz approach to control, means not only benefits, but additional costs and inconvenience for producers and suppliers, who have to consider the long chain from a coffee bean to cup.101

Elements of the Utz control mechanisms, for example the web-based traceability system, can be borrowed by producers and suppliers of sustainable biofuels.

\section{Final Reflections and Conclusions}

In line with the overall development of today, industries, their products and production processes need to be sustainable. This aim can be achieved through a variety of means, including the use of sustainability criteria, sustainability standards and eco-labels for products. Taking the coffee sector as an example, sustainable quality of coffee and its sustainable production are regulated through sustainability criteria, incorporated in a number of co-existing voluntary sustainability standards. This approach has already been functioning for some time, and certain practical experience has been gained. The knowledge from the coffee sector should be thoroughly analyzed. It can be useful for the subsequent research on how frameworks with sustainability criteria for similar products of an agricultural origin can be built up and function. Elements of the governance approach towards sustainability in the coffee sector can be efficiently borrowed by other industries.

The approach to use sustainability criteria in the coffee sector is interesting: internationally, there co-exist voluntary sustainability standards without coming into conflict. In some cases, the sustainability standards regulate different issues, and producing farms can be certified according to several sustainability standards. The sustainability standards are mostly promoted with the help of NGO initiatives.

101 Kolk, A. (2011), Mainstreaming sustainable coffee, p. 11. 
Critique can be made that the situation in the coffee sector can be organized more efficiently. Because of the reliance on different sustainability standards and lack of coordination of efforts and strategies, the involved actors at the coffee market are competing with each other on the content of sustainability criteria.102 There is no agreed definition of the concepts "sustainable coffee" and "sustainable production of coffee", which is a weakness.

For consumers, who wish to take account of sustainability factors in their purchasing decisions, the co-existence of similar sustainability standards complicates rather than facilitates transparency. 103 In many cases consumers do not understand the difference between various sorts of coffee. This indicates that longer going regulations, probably of a binding legal character, are needed. The consumers should be supplied with more information. A homogeneous, globally acknowledged sustainability standard for coffee with a clearly defined concept "sustainable coffee" and guidelines on what makes the production of coffee sustainable can be suggested as an alternative for the future development. Still, this initiative has a long way to go in terms of broad market acceptance and transparency. 104 There is also a question to what extent such a standard is needed.

As an example for the future research, comparison of the environmental sustainability criteria and their control mechanisms in the coffee and biofuels sectors can be suggested. From the first sight, the biofuel and coffee industries do not have much in common: they deal with completely different products. A deeper insight view, however, highlights that there exist many similarities, especially if biofuels of an agricultural origin are compared with coffee. 105 The production processes of these products share similar sustainability concerns. For example, the overwhelming amount of coffee is farmed in developing countries with favorable climate in the South 106 and exported to developed countries in the North. 107 The same tendency can be observed in the biofuel industry. 108

102 Bitzer, V., Francken, M., Glasbergen, P. (2008), Intersectoral partnerships for a sustainable coffee chain: Really addressing sustainability or just picking (coffee) cherries?, p. 282.

103 Neilson, J., Pritchard, B. (2007), Green Coffee? The Contradictions of Global Sustainability Initiatives from an Indian Perspective, p. 320

104 Giovannucci, D. (2001), Sustainable Coffee Survey of the North American Specialty Coffee Industry, p. 20.

105 Coffee oil, extracted from coffee grounds and defective coffee beans was found to be a high quality and cost-effective feedstock for biodiesel production compared to other waste sources [Al-Hamamre, Z., Foerster, S., Hartmann, F., Kröger, M., Kaltschmitt, M. (2012), Oil extracted from spent coffee grounds as a renewable source for fatty acid methyl ester manufacturing, p. 70].

106 Rice, R. (2003), Coffee production in a time of crisis: social and environmental connections, pp. 223 - 224; Santato, A., Bertoldi, D., Perini, M., Camin, F., Larcher, R. (2012), Using elemental profiles and stable isotopes to trace the origin of green coffee beans on the global market, $\mathrm{p}$. 1132 .

107 Ponte, S. (2004), Standards and Sustainability in the Coffee Sector, A Global Value Chain Approach, p. 2; Fridell, G. (2007), Fair-Trade Coffee and Commodity Fetishism: The Limits of Market-Driven Social Justice, p. 80.

108 E.g. the ideal land for sugarcane and oil palm trees, which are among the most energy efficient biofuel feedstocks, is primarily located in developing countries in tropical and sub-tropical climates [IPC Discussion Paper, October 2006, WTO Disciplines and Biofuels: Opportunities and Constraints in the Creation of a Global Marketplace, p. 3].
Besides, there are overlapping markets for both sustainable and unsustainable coffee. A situation of the same kind might be developed in the biofuel industry, because sustainability criteria for biofuels legislated in one region are not binding for producers around the world, and it is free to produce unsustainable biofuels. This suggests that in the long run sustainable and unsustainable biofuels have potential to co-exist.

\section{Acknowledgements}

I would like to thank the Law Faculty at Lund University, Sweden, and Vilhelm Persson, its Head, for providing extremely convenient research conditions. I would like to express my deep gratitude to Annika Nilsson, Karin Ericsson and Bengt Lundell, my research supervisors, for their guidance and useful critiques of the present research work. My special thanks are extended to the Johan and Jakob Söderberg Funding in Stockholm for its financial support.

\section{REFERENCES}

[1] Fair Trade International (2011), Fair Trade Standard for Coffee for Small Producer Organizations; can be found at http://www.fairtrade.net/fileadmin/user_upload/content/2009 /standards/documents/2012-04-01_EN_SPO_Coffee.pdf, last visited 29-08-2013.

[2] The UTZ Certified (2010), Code of Conduct for Coffee, November 2010. November 2010; can be found athttp://www.utzcertified-trainingcenter.com/home/images/st ories/library_files/EN+UTZ+Code+of+Conduct+Coffee.pdf, last visited 02-09-2013.

[3] Adams, M.A., Ghaly, A.E. (2007), The foundations of a multi-criteria evaluation methodology for assessing sustainability, International Journal of Sustainable Development and World Ecology, vol. 14, issue 5, pp. 437-449; can be found at http://www.tandfonline.com/doi/ab s/10.1080/13504500709469744, last visited 22-08-2013.

[4] Al-Hamamre, Z., Foerster, S., Hartmann, F., Kröger, M., Kaltschmitt, M. (2012), Oil extracted from spent coffee grounds as a renewable source for fatty acid methyl ester manufacturing, Fuel, June 2012, vol. 96, pp. 70-76; can be found at

http://www.sciencedirect.com/science/article/pii/S00162361 12000464, last visited 27-08-2013.

[5] Bitzer, V., Francken, M., Glasbergen, P. (2008), Intersectoral partnerships for a sustainable coffee chain: Really addressing sustainability or just picking (coffee) cherries?, Global Environmental Change, May 2008, vol. 18, issue 2, pp. 271-284; can be found at http://www.sciencedirect.com/science/article/pii/S09593780 08000137, last visited 22-08-2013.

[6] Borkhataria, R., Collazo, J. A., Groom, M. J., Jordan-Garcia, A. (2012). Shade-grown coffee in Puerto Rico: Opportunities to preserve biodiversity while reinvigorating a struggling agricultural commodity. Agriculture, Ecosystems \& 
Environment, 149, 164-170; can be found at http://www.sciencedirect.com/science/article/pii/S01678809 10003543\#, last visited 07-10-2013.

[7] Coffee Politics: Coffee Issues and Social Aspects, Coffee Sustainability; can be found athttp://www.coffeeresearch.org/politics/overview.htm, last visited 28-08-2013.

[8] Davenport, E., \& Low, W. (2013). From trust to compliance: accountability in the fair trade movement. Social Enterprise Journal, 9(1), 88-101; can be found at http://www.emeraldinsight.com/journals.htm?articleid=1709 0298\&show=abstract, last visited 07-10-2013.

[9] Dörr, A., C. (2009), A Comparative Analysis of Certification Schemes in the Brazilian Fruit Sector, in Annals of the University of Petroşani, Economics, 9(1), 2009, ISSN 1582-5949, pp. 217-230; can be found athttp://www.upet.ro/annals/pdf/annals-2009-part1.pdf, last visited 07-10-2013.

[10] Elder, S. D., Zerriffi, H., le Billon, P. (2013). Is Fairtrade certification greening agricultural practices? An analysis of Fairtrade environmental standards in Rwanda. Journal of Rural Studies, 32, 264-274; can be found athttp://www.sciencedirect.com/science/article/pii/S0743016 713000612\#, last visited 07-10-2013.

[11] Fair Trade Coffee: A Growing Market Trend (2007); can be found at http://blogcritics.org/fair-trade-coffee-a-growing-m arket/, last visited 29-08-2013.

[12] Fox, T. (2007), The Coffee System: What Standard, What Means? "Fair Trade" and "UTZ"; can be found at http://www-irps.ucsd.edu/assets/020/8416.pdf, last visited 07-10-2013.

[13] Fridell, G. (2007), Fair-Trade Coffee and Commodity Fetishism: The Limits of Market-Driven Social Justice, Historical Materialism, vol. 15, N. 4, 2007 , pp. 79-104; can be found at http://www. ingentaconnect.com/content/brill/hm/2007/00000015/00000 004/art00003, last visited 27-08-2013.

[14] Giovannucci, D. (2001), Sustainable Coffee Survey of the North American Specialty Coffee Industry, can be found at http://www.cloudforestcoffee.com/PDF\%20Files/Specialty\% 20Coffee\%20Report.pdf, last visited 22-08-2013.

[15] Greenberg, R. (2001), Criteria Working Group Thought Paper, the Smithsonian Institution; can be found athttp://nationalzoo.si.edu/scbi/migratorybirds/coffee/though tpaper.pdf, last visited 23-08-2013.

[16] Haight, C. (2011), The Problem with Fair Trade Coffee, Stanford Social Innovation Review; can be found at http://www.ssireview.org/articles/entry/the_problem_with_f air_trade_coffee, last visited 29-08-2013.

[17] Ingenbleek, P. T., \& Reinders, M. J. (2013). The development of a market for sustainable coffee in the Netherlands: Rethinking the contribution of fair trade. Journal of business ethics, 461-474; can be found athttp://download.springer.com/static/pdf/903/art\%253A10.1 007\%252Fs10551-012-1316-4.pdf?auth66=1381394149_23 0b255164419cd9886a473b7e84888a\&ext=.pdf; last visited 08-10-2013.

[18] IPC Discussion Paper, October 2006, WTO Disciplines and Biofuels: Opportunities and Constraints in the Creation of a
Global Marketplace, International Food \& Agricultural Trade Policy Council; can be found

athttp://www.agritrade.org/Publications/DiscussionPapers/W TO_Disciplines_Biofuels.pdf, last visited 27-08-2013.

[19] Kim, D., \& Jang, S. S. (2013, January). Price Placebo Effects: Consumers May Get What They Pay For. In The 18 th Annual Graduate Education and Graduate Student Research Conference in Hospitality and Tourism; can be found at http://conferencesdev.wsu.edu/conferences/hospitality/pdf/C onferenceProceedings.pdf\#page $=130, \quad$ last visited 07-10-2013.

[20] Kolk, A. (2005), Corporate Social Responsibility in the Coffee Sector: The Dynamics of MNC Responses and Code Development, University of Amsterdam, in European Management Journal, April 2005, vol. 23, issue 2, pp. 228-236; can be found at http://www.sciencedirect.com/science/article/pii/S02632373 05000289, last visited 28-08-2013.

[21] Kocken, M. (2006), Sixty Years of Fair Trade, a brief history of the Fair Trade movement, EFTA; can be found at http://www.european-fair-trade-association.org/efta/Doc/His tory.pdf, last visited 29-08-2013.

[22] Low, W., Davenport, E. (2006), Mainstreaming fair trade: adoption, assimilation, appropriation, Journal of Strategic Marketing, 2006, vol. 14, issue 4, pp. 315 -327; can be found at

http://www.tandfonline.com/doi/pdf/10.1080/096525406009 47912, last visited 02-09-2013.

[23] Montavlo, K. (2006), Beans and Leaves, Gourmet Retailer, January 2006, vol. 27, issue 1, pp. $87-92$.

[24] Moore, G. (2004), The Fair Trade Movement: Parameters, Issues and Future Research, Journal of Business Ethics, 2004, vol. 53, pp. 73 - 86; can be found at http://link.springer.com/content/pdf/10.1023\%2FB\%3ABUS I.0000039400.57827.c3.pdf, last visited 02-09-2013.

[25] Muradian, R., Pelupessy, W. (2005), Governing the Coffee Chain: The Role of Voluntary Regulatory Systems, Tilburg University, the Netherlands, World Development, December 2005, vol. 33, no. 12, pp. 2029 - 2044; can be found at http://ac.els-cdn.com/S0305750X05001567/1-s2.0-S030575 0X05001567-main.pdf? tid=d73dcdbe-0fce-11e3-8b5b-000 00aab0f26\&acdnat $=137 \overline{7} 686861 \quad 6 \mathrm{~d} 477 \mathrm{~b} 67 \mathrm{dd} 96 \mathrm{fba} 64 \mathrm{c} 07 \mathrm{ab}$ afb695f145, last visited 28-08-2013.

[26] Murray, D., Raynolds, L., Taylor, P. (2006), The future of Fair Trade coffee: dilemmas facing Latin America's small-scale producers, Development in Practice, April 2006, vol. 16, N. 2, pp. 179 - 192; can be found athttp://www.tandfonline.com/doi/pdf/10.1080/09614520600 562397, last visited 29-08-2013.

[27] Neilson, J., Pritchard, B. (2007), Green Coffee? The Contradictions of Global Sustainability Initiatives from an Indian Perspective,Development Policy Review, 2007, vol. 25, issue 3, pp. 311 - 331; can be found athttp://onlinelibrary.wiley.com/doi/10.1111/j.1467-7679.20 07.00372.x/pdf, last visited 03-09-2013.

[28] Ponte, S. (2002), The "Latte Revolution"? Regulation, Markets and Consumption in the Global Coffee Chain, World Development, July 2002, vol. 30, issue 7, pp. 1099-1122; can be found athttp://www.sciencedirect.com/science/article /pii/S0305750X02000323, last visited 22-08-2013. 
[29] Ponte, S. (2004), Standards and Sustainability in the Coffee Sector, A Global Value Chain Approach, Danish Institute for International Studies, published by the International Institute for Sustainable Development; can be found athttp://www.ucema.edu.ar/u/hr/Cursos/Casos/Caso_Cafe/Po nte_2004_Standards_and_sustainability_in_coffee_sector.pd f, last visited 20-08-2013.

[30] Raynolds, L., Murray, D., Taylor, P. (2004), Fair trade coffee: building producer capacity via global networks, Journal of International Development, 2004, vol. 16, pp. $1109-1121$; can be found at http://onlinelibrary.wiley.com/doi/10.1002/ji d.1136/pdf, last visited 02-09-2013.

[31] Rice, P., McLean, J. (1999), Sustainable Coffee at the Crossroads, A White Paper Prepared For The Consumer's Choice Council; can be found at http://www.greenbeanery.ca/bean/documents/sustainableCof fee.pdf, last visited 27-08-2013.

[32] Rice, R. (2003), Coffee production in a time of crisis: social and environmental connections, SAIS Review, Winter-Spring 2003, vol. 23, N. 1, pp. 221-245; can be found at http://cftn.ca/sites/default/files/AcademicLiterature/ coffee $\% 20$ production.pdf, last visited 28-08-2013.

[33] Santato, A., Bertoldi, D., Perini, M., Camin, F., Larcher, R. (2012), Using elemental profiles and stable isotopes to trace the origin of green coffee beans on the global market, Journal of Mass Spectrometry, January 2012, vol. 47, issue 9, pp. 1132-1140; can be found at http://onlinelibrary.wiley.com/doi/10.1002/jms.3018/pdf, last visited 27-08-2013.
[34] Sexsmith, K., \& Potts, J. (2009), Voluntary Sustainability Standards and Value Chain Governance, a background paper, published by the International Institute for Sustainable Development (IISD), can be found athttp://search.iisd.org/pdf/2009/voluntary_sustainability_sta ndards_gov.pdf, last visited 07-10-2013.

[35] Slob, B. (2006), A fair share for smallholders. A value chain analysis of the coffee, published by SOMO - Centre for research on Multinational Corporations; can be found at $\mathrm{http}: / /$ somo.nl/html/paginas/pdf/A fair share for_smallhold ers_2006_EN.pdf, last visited 07-10-2013.

[36] Smith Maguire, J., \& Hu, D. (2013). Not a simple coffee shop: local, global and glocal dimensions of the consumption of Starbucks in

China. Social Identities, (ahead-of-print), 1-15; can be found at http://www.tandfonline.com/doi/pdf/10.1080/13504630.201 3.835509, last visited 07-10-2013.

[37] Trade Standards Practitioners Network, TSPN, (2010), Food-related Voluntary Sustainability Standards: A Strategy Guide for PolicyMakers, a draft working document for TSPN Members Meeting, Bern, 18 November 2010; can be found athttp://unfss.files.wordpress.com/2013/02/tspn-guide-v9_1. pdf, last visited 08-10-2013.

[38] Fair Trade web-site, http://www.fairtrade.net, last visited 07-10-2013.

[39] ISEAL web-site, http://www.isealalliance.org/about-us, last visited 29-08-2013.

[40] The UTZ Certified web-site, https://www.utzcertified.org/, last visited 07-10-2013. 